\title{
Bacterial direct-fed microbials fail to reduce methane emissions in primiparous lactating dairy cows
}

\author{
Jeyamalar Jeyanathan ${ }^{1,2}$, Cécile Martin ${ }^{1}$, Maguy Eugène ${ }^{1}$, Anne Ferlay ${ }^{1}$, Milka Popova ${ }^{1}$ and Diego P. Morgavi ${ }^{1 *}$ (D)
}

\begin{abstract}
Direct-fed microbials (DFM) are considered as a promising technique to improve animal productivity without affecting animal health or harming the environment. The potential of three bacterial DFM to reduce methane $\left(\mathrm{CH}_{4}\right)$ emissions, modulate ruminal fermentation, milk production and composition of primiparous dairy cows was examined in this study. As previous reports have shown that DFM respond differently to different diets, two contrasting diets were used in this study. Eight lactating primiparous cows were randomly divided into two groups that were fed a corn silage-based, high-starch diet (HSD) or a grass silage-based, high-fiber diet (HFD). Cows in each dietary group were randomly assigned to four treatments in a $4 \times 4$ Latin square design. The bacterial DFM used were selected for their proven $\mathrm{CH}_{4}$-reducing effect in vitro. Treatments included control (without DFM) and 3 DFM treatments: Propionibacterium freudenreichii 53-W $\left(2.9 \times 10^{10}\right.$ colony forming units (CFU)/cow per day), Lactobacillus pentosus D31 (3.6 $\times 10^{11} \mathrm{CFU} / \mathrm{Cow}$ per day) and Lactobacillus bulgaricus D1 (4.6 $\times 10^{10} \mathrm{CFU} / \mathrm{Cow}$ per day). Each experimental period included 4 weeks of treatment and 1 week of wash-out, with measures performed in the fourth week of the treatment period. Enteric $\mathrm{CH}_{4}$ emissions were measured during 3 consecutive days using respiration chambers. Rumen samples were collected for ruminal fermentation parameters and quantitative microbial analyses. Milk samples were collected for composition analysis. Body weight of cows were recorded the end of each treatment period. Irrespective of diet, no mitigating effect of DFM was observed on $\mathrm{CH}_{4}$ emissions in dairy cows. In contrast, Propionibacterium increased $\mathrm{CH}_{4}$ intensity by $27 \%\left(\mathrm{~g} \mathrm{CH}_{4} / \mathrm{kg}\right.$ milk) in cows fed HSD. There was no effect of DFM on other fermentation parameters and on bacterial, archaeal and protozoal numbers. Similarly, the effect of DFM on milk fatty acid composition was negligible. Propionibacterium and L. pentosus DFM tended to increase body weight gain with HSD. We conclude that, contrary to the effect previously observed in vitro, bacterial DFM Propionibacterium freudenreichii 53-W, Lactobacillus pentosus D31 and Lactobacillus bulgaricus D1 did not alter ruminal fermentation and failed to reduce $\mathrm{CH}_{4}$ emissions in lactating primiparous cows fed high-starch or high-fiber diets.
\end{abstract}

Keywords: Bacterial direct-fed microbial, Dairy cow, Methane, Milk fatty acid

\section{Background}

Livestock farming is considered a major contributor to anthropogenic methane $\left(\mathrm{CH}_{4}\right)$ emissions, which is mainly attributed to ruminants [1]. Methane production is also energetically wasteful for ruminants resulting in a loss of $2-12 \%$ of the ingested feed energy [2]. Several dietary strategies based on additives and supplements have been

\footnotetext{
* Correspondence: diego.morgavi@inra.fr

${ }^{1}$ Université Clermont Auvergne, INRA, VetAgro Sup, UMR 1213 Herbivores,

F-63122 Saint-Genès-Champanelle, France

Full list of author information is available at the end of the article
}

proposed to mitigate rumen methanogenesis but only few of them have shown persistent effect in vivo without negative impacts to the host animal and the environment $[3,4]$. Use of direct-fed microbials (DFM) is one possible option that could be sustainable and easily acceptable by both consumers and producers [5].

Direct-fed microbials are used in the dairy sector to improve animal productivity and health [6, 7]. Propionibacterium and Lactobacillus spp. alone or in combination are the most common bacterial DFM used in ruminant production [7]. A metabolic aspect that

(c) The Author(s). 2019 Open Access This article is distributed under the terms of the Creative Commons Attribution 4.0 International License (http://creativecommons.org/licenses/by/4.0/), which permits unrestricted use, distribution, and 
characterizes these bacterial species is the production of propionate, which is a $\mathrm{H}_{2}$-consuming reaction [8]. Promoting this pathway is expected to produce less $\mathrm{H}_{2}$ and consequently less $\mathrm{CH}_{4}$ in the rumen. However, in vivo studies using Propionibacterium and/or Lactobacillus spp. as modulators of enteric $\mathrm{CH}_{4}$ production showed contrasting results with decreases, no effect or even increases in $\mathrm{CH}_{4}$ emissions [4, 9-11]. These differences could be originated from several factors such as type of ruminant, physiological stage, and diet, but also due to differences in the strains of DFM used.

The bacterial DFM used in this study: Propionibacterium freudenreichii 53-W, Lactobacillus pentosus D31 and Lactobacillus bulgaricus D1 were previously selected for their $\mathrm{CH}_{4}$-decreasing effect in vitro [9]. They were also tested in adult wethers fed a hay-based diet $(70 \%$ natural grassland hay and $30 \%$ concentrate) at maintenance with contrasting results [9]. Whereas $L$. pentosus reduced $\mathrm{CH}_{4}$ emissions (g/kg DMI), no effect was observed for $L$. bulgaricus and P. freudenreichii increased $\mathrm{CH}_{4}$ emissions ( $\left.\mathrm{g} / \mathrm{kg} \mathrm{DMI}\right)$. The efficacy of DFM may differ depending on the animal species, physiological stage and diet $[4,10-12]$. The objective of this study was to examine the potential of three selected bacterial DFM to modulate ruminal fermentation in lactating primiparous cows. The effect on milk production and composition, more particularly fatty acid (FA) composition, was also monitored. As efficacy of bacterial DFM has been shown to be affected by diet a high-starch diet (HSD) and a high-fiber diet (HFD) were used in this study.

\section{Methods}

This study was conducted using the animal facilities at the French National Institute for Agricultural Research (INRA) in Theix. Procedures on animals used in this study complied with the guidelines for animal research of the French Ministry of Agriculture and all other applicable National and European guidelines and regulations.

\section{Animals, experimental design, and diets}

Eight lactating primiparous Holstein cows (age of $2.9 \pm$ 0.4 years, mean $\pm \mathrm{SD}$ ) were housed in individual stalls during the study. The cows were randomly allocated into two balanced groups of four animals and fed two different basal diets: one based on corn silage, hereafter called high-starch diet (HSD), and the second based on grass silage, hereafter called high-fiber diet (HFD; Table 1). At the start of the study, average daily milk production was $22.8 \pm 4.9$ and $22.6 \pm 1.1 \mathrm{~kg} / \mathrm{cow}$, days in milk $83.2 \pm 11.3$ and $91 \pm 15.6$ days, and body weight $587.5 \pm 51.1$ and $585.7 \pm 32.3 \mathrm{~kg}$ for cows fed HSD and HFD, respectively.

Cows in each group were randomly assigned to four treatments in a $4 \times 4$ Latin square design that were run
Table 1 Ingredients and chemical composition of the highstarch and high-fiber control diets used in this study

\begin{tabular}{|c|c|c|}
\hline \multirow[t]{2}{*}{ Items } & \multicolumn{2}{|l|}{ Control diets $^{a}$} \\
\hline & High-starch diet & High-fiber diet \\
\hline \multicolumn{3}{|l|}{ Ingredients, \% of DM } \\
\hline Corn silage & 44.0 & - \\
\hline Grass silage & _ & 55.0 \\
\hline Hay & 11.0 & - \\
\hline Grain mix ${ }^{c}$ & 34.2 & - \\
\hline Citrus pulp & - & 12.0 \\
\hline Dehydrated beet pulp & _- & 20.0 \\
\hline Molasses, beet & - & 5.0 \\
\hline Soybean meal & 8.7 & 8.0 \\
\hline Urea & 1.0 & - \\
\hline Cane molasses & 1.1 & - \\
\hline \multicolumn{3}{|c|}{ Chemical composition, \% of DM } \\
\hline $\mathrm{OM}$ & 92.2 & 85.1 \\
\hline $\mathrm{CP}$ & 12.5 & 12.2 \\
\hline NDF & 35.4 & 48.4 \\
\hline ADF & 19.5 & 29.3 \\
\hline Starch & 27.4 & 1.8 \\
\hline Ether extract & 2.3 & 2.3 \\
\hline \multicolumn{3}{|c|}{ Fatty acids (FA), g/100 g of total FA } \\
\hline $12: 0$ & 0.17 & 0.34 \\
\hline 14:0 & 0.35 & 0.89 \\
\hline $16: 0$ & 20.7 & 21.7 \\
\hline cis-9 16:1 & 0.72 & 2.03 \\
\hline $18: 0$ & 2.57 & 2.13 \\
\hline cis-9 18:1 & 19.4 & 9.8 \\
\hline $18: 2 n-6$ & 44.9 & 28.5 \\
\hline $18: 3 n-3$ & 7.3 & 28.0 \\
\hline $\mathrm{GE}, \mathrm{MJ} / \mathrm{kg} \mathrm{DM}$ & 16.8 & 16.9 \\
\hline
\end{tabular}

${ }^{a}$ Each cow was fed $250 \mathrm{~g}$ mineral mix comprising (g/kg): P, 2.5; Ca, 20; Mg, 4.5; $\mathrm{Na}$, 3.5 (Galaphos Midi Duo GR, CCPA, Aurillac, France)

${ }^{\mathrm{b}}$ Ingredients not included

'Composition: barley (14.1\% of DM), wheat (10.9\% of DM) and corn $(9.2 \%$ of DM)

in parallel. The treatments were 1) Control without DFM (CTL), 2) Propionibacterium freudenreichii 53-W $\left(2.9 \times 10^{10}\right.$ colony forming units (CFU)/cow per day), 3) Lactobacillus pentosus D31 $\left(3.6 \times 10^{11} \mathrm{CFU} / \mathrm{cow}\right.$ per day $)$ and 4) Lactobacillus bulgaricus D1 $\left(4.6 \times 10^{10} \mathrm{CFU} / \mathrm{cow}\right.$ per day). The dose of each DFM (CFU/mL rumen fluid) was chosen considering cost of production and the results from an earlier study with the same DFM preparations administered to sheep fed a hay-based diet [9]. Propionibacterium freudenreichii 53-W (DSM 20271) was obtained from DSMZ (Deutsche Sammlung von Mikroorganismen und Zellkulturen $\mathrm{GmbH}$, Braunschweig, Germany) and 
both Lactobacillus species were obtained from Danone culture collection (Danone Research, Palaiseau, France). The DFM preparations used in this study were obtained from Danone Research (Palaiseau, France) in a frozen pellet form. Their viability was checked prior to the study. Weighed pellets were thawed in $0.1 \%$ sterile peptone solution, serially diluted and inoculated onto agar plates (DSMZ medium 91 for $P$. freudenreichii and MRS medium for both Lactobacillus species). Plates were incubated at $39^{\circ} \mathrm{C}$ for $48 \mathrm{~h}$ before colony counts. Results were in agreement with the quantity of CFU stated by the manufacturer.

Diets were formulated at the beginning of the study to meet the energy and protein requirements for maintenance and lactation of dairy cows based on INRA nutritional recommendation for ruminants [13]. Diets were free from antibiotics, chemical buffer and yeast to avoid potential interfering effect with the effect of bacterial DFM tested in this study. Two weeks before starting the study, cows in both groups were fed CTL diet ad libitum. Then, throughout the study, feeds were restricted to $90 \%$ of their ad libitum intake to ensure complete consumption of the diet. Each experimental period (5 weeks) consisted of 4 weeks of treatment and 1 week of washout, without DFM supplementation. Cows were fed twice daily with $60 \%$ of the daily ration at $07: 00 \mathrm{~h}$ and $40 \%$ at 16:00 h. During the treatment period, DFM preparations were administered during the morning feeding. Each day, just before feed distribution, the appropriate amount of pellets were thawed in $50 \mathrm{~mL}$ of $0.1 \%$ sterile peptone solution at room temperature. To ensure the entire DFM consumption, the $50-\mathrm{mL}$ doses were mixed with a small portion of silage (about $500 \mathrm{~g}$ sampled from their diet) and offered before feeding. The amounts of feed offered and refused were weighed daily to estimate DMI. Cows were allowed continuous access to water and water intake was measured for each cow. The body weight of each animal was recorded at the end of each experimental period, $3 \mathrm{~h}$ after morning feeding.

\section{Measurements and analyses Feed analysis}

The dry matter content of each feed ingredient was determined $\left(103^{\circ} \mathrm{C}\right.$ for $24 \mathrm{~h}$, ISO 6496 [14]) weekly for hay and concentrates and twice per week for silages throughout the experimental period. During the last week of each experimental period (week 4), silage, hay and concentrates were sampled (about $100 \mathrm{~g}$ ) daily and were pooled at the end of the week. Samples of silage were stored at $-20^{\circ} \mathrm{C}$ and samples of hay and concentrates were stored at $4{ }^{\circ} \mathrm{C}$. At the end of the study, all feed samples were dried in an oven and ground (1-mm screen) before chemical analyses (InVivo Labs, Saint Nolff, France). Organic matter was determined by ashing samples at $550^{\circ} \mathrm{C}$ for $6 \mathrm{~h}$ (method 942.05; [15]). Fiber (NDF and ADF) was determined by sequential procedures [16] after pre-treatment with amylase and expressed exclusive of residual ash. Total $\mathrm{N}$ was analyzed by combustion according to the Dumas method (method 968.06; [15]) and CP content was calculated as $\mathrm{N} \times 6.25$. Ether extract was determined after acid hydrolysis (method 954.02; [15]). Starch content was analyzed using an enzymatic method [17]. Briefly, samples are incubated in a shaking water bath with pancreatic $\alpha$-amylase and amyloglucosidase for $16 \mathrm{~h}$ at $37^{\circ} \mathrm{C}$, during which starch is hydrolyzed to $D$-glucose by the combined action of the enzymes. Then, the $D$-glucose is measured with glucose oxidase/peroxidase reagent. The gross energy (GE) was analyzed by isoperibolic calorimetry (C200 model; IKA, Staufen, Germany).

\section{Enteric methane}

In the last week of the experimental period (week 4, days 2-4) enteric $\mathrm{CH}_{4}$ emission was determined using individual open circuit respiration chambers (1 cow/chamber) for 3 consecutive days as described in Guyader et al. [18]. Cows were allocated to the same chamber so that the DFM effect was not confounded with the chamber effect. Air leaks from the chambers were examined before the start of the experiment using water-based smoke machines (Kool Light-FOGGER 1500E; EPICAP, Saint-Symphorien d'Ozon, France). The chambers operated at a slightly negative pressure, with an air flow averaging $743.6 \pm 19.61,792.1 \pm 17.89,771.7 \pm 14.40$ and 756.6 $\pm 18.43 \mathrm{~m}^{3} / \mathrm{h}$ for periods $1,2,3$ and 4 respectively. Continuous air sampling was performed in each chamber at a $0.1-\mathrm{Hz}$ sample frequency for $5 \mathrm{~min}$ every $25 \mathrm{~min}$ and analyzed for $\mathrm{CH}_{4}$ gas concentrations with an infrared gas analyzer (Ultramat 6, Siemens, Karlsruhe, Germany). The chambers were opened twice daily at 07:00 $\mathrm{h}$ and 15:00 $\mathrm{h}$ for about $20 \mathrm{~min}$ for milking and subsequent feeding. The gas analyser was calibrated at the start of every $\mathrm{CH}_{4}$ measurement period with pure $\mathrm{N}_{2}$ and a certified standard gas mixture of $\mathrm{CO}_{2}\left(1.36 \mathrm{~g} / \mathrm{m}^{3}\right)$ and $\mathrm{CH}_{4}\left(0.459 \mathrm{~g} / \mathrm{m}^{3}\right)$. Real time gas emissions in a chamber were calculated by the difference between chamber and ambient gas concentrations multiplied by the airflow corrected for temperature, relative humidity, and pressure according to the Wexler equation [19]. Calculations of $\mathrm{CH}_{4}$ yield ( $\mathrm{g}$ $\mathrm{CH}_{4} / \mathrm{kg} \mathrm{DMI}$ ) and intensity ( $\mathrm{g} \mathrm{CH}_{4} / \mathrm{kg}$ milk) were done using data on DMI and milk production when cows were in chambers.

\section{Ruminal fermentation and microbes}

In the last week of the experimental period (week 4) rumen samples (approximately $500 \mathrm{~mL}$ ) were collected $3 \mathrm{~h}$ after the morning feeding for two non-consecutive days (day 1 and 5) using a stomach tube fitted with a 
vacuum pump. The samples were subjected to visual examination to ensure that they were not contaminated with saliva. Values of $\mathrm{pH}$ were also used as an additional control. Samples suspected to be contaminated were removed, and fresh samples were taken.

The $\mathrm{pH}$ of each sample was recorded immediately with a portable $\mathrm{pH}$-meter (CG840, electrode $\mathrm{Ag} / \mathrm{AgCl}$, Schott Gerate, Hofhein, Germany). One aliquot of rumen contents (about $200 \mathrm{~mL}$ ) was strained through a polyester monofilament fabric (mesh size $250 \mu \mathrm{m}$ ) and the filtrate was sampled for analysis of VFA, ammonia-N $\left(\mathrm{NH}_{3}-\mathrm{N}\right)$, and protozoa counts. Samples for VFA were prepared by transferring $0.8 \mathrm{~mL}$ filtrate into a micro-tube containing $0.5 \mathrm{~mL}$ of a crotonic-metaphosphoric acid solution (crotonic acid $0.4 \% \mathrm{wt} / \mathrm{vol}$, metaphosphoric acid $2 \% \mathrm{wt} / \mathrm{vol}$, in $\mathrm{HCl} 0.5$ $\mathrm{mol} / \mathrm{L}$ ) and stored at $-20^{\circ} \mathrm{C}$ until analysis. For $\mathrm{NH}_{3}-\mathrm{N}$, $1 \mathrm{~mL}$ of rumen filtrate was mixed with $0.1 \mathrm{~mL}$ of $5 \%$ $\mathrm{H}_{3} \mathrm{PO}_{4}$ and stored at $-20^{\circ} \mathrm{C}$ until analysis. For protozoa counts, $2 \mathrm{~mL}$ of the rumen filtrate was mixed with $2 \mathrm{~mL}$ of methyl-green-formalin and saline solution (MFS) and preserved from light until counting. For quantitative microbial analysis, another aliquot (about $200 \mathrm{~mL}$ ) of rumen contents was frozen immediately at $-80{ }^{\circ} \mathrm{C}$ and subsequently lyophilized. Lyophilized samples were then ground and stored at $-80^{\circ} \mathrm{C}$ until DNA was extracted. For each sampling time, unfiltered rumen contents were dried at $103^{\circ} \mathrm{C}$ for $24 \mathrm{~h}$ for DM determination.

Volatile fatty acid concentrations were determined by gas chromatography [20] on a Perkin-Elmer Clarus 580 GC (Perkin Elmer, Courtaboeuf, France) equipped with a column Stabilwax - DA ( $30 \mathrm{~m} \times 0.53 \mathrm{~mm}$ i.d.) and using crotonic acid as the internal standard. The concentration of $\mathrm{NH}_{3}-\mathrm{N}$ in rumen fluid was determined using the Berthelot reaction [21]. Rumen fluid/MFS solutions were diluted in an equal volume of phosphate buffer saline solution (PBS) and protozoa were enumerated in a Neubaeur chamber [22].

Total genomic DNA was extracted from ground lyophilized rumen samples using a bead beating and column purification (QIAamp DNA stool mini kit, Qiagen, Valencia, CA) method [23]. The yield and purity of the extracted DNA was determined using a NanoDrop spectrophotometer (Thermo Scientific, Wilmington, DE) and stored at $-20^{\circ} \mathrm{C}$. The primers used in this study are listed in Additional file 1: Table S1.

Quantitative real-time PCR assays were performed on a StepOne ${ }^{\mathrm{m} n}$ system (Applied Biosystems, Courtabeuf, France) using SYBR Ex Taq ${ }^{\text {Tw }}$ pre mixture (Takara Bio Inc., Otsu, Japan). Amplification of 16S rRNA genes of $P$. freudenreichii and L. bulgaricus, and intergenic spacer regions (16S-23S) of $L$. pentosus were performed as described in Jeyanathan et al. [9]. Quantification of bacterial 16S rRNA and methanogenic mcrA genes were performed as previously described [24].

\section{Milk production and composition}

Cows were milked twice daily at $07: 00 \mathrm{~h}$ and $15: 00 \mathrm{~h}$, and milk production of individual animals was recorded electronically throughout the study except for the last week of treatment period (week 4) when cows were in chambers. In week 4 , milking and weighing were done manually. Samples of milk for the measurement of fat, protein, and lactose were collected individually once per week and treated with preservative (bronopol-B2; Trillaud, Surgeres, France). Samples of unpreserved milk were also collected at each milking over 2 non-consecutive days (Tuesday and Thursday) of week 4 of the experimental period and stored at $-20^{\circ} \mathrm{C}$ until analysis for FA composition.

Milk fat and protein contents were determined by mid-infrared spectrophotometry using a Milkoscan 4000 (Foss Electric, Hillerød, Denmark). The FA of the lyophilized milk samples were methylated and analyzed as before [25] with some modifications: $2 \mathrm{~mL}$ of $0.5 \mathrm{~mol} / \mathrm{L}$ sodium methanolate and $1 \mathrm{~mL}$ hexane were mixed with the lyophilised milk at $50^{\circ} \mathrm{C}$ for $15 \mathrm{~min}$, followed by the addition of $1 \mathrm{~mL} 12 \mathrm{~mol} / \mathrm{L} \mathrm{HCl} 5 \%$ in methanol $(v / v)$ at $50^{\circ} \mathrm{C}$ for $15 \mathrm{~min}$. The fatty acid methyl esters (FAME) were washed with a saturated $\mathrm{K}_{2} \mathrm{CO}_{3}$ solution and recovered with $1.5 \mathrm{~mL}$ hexane. The FAME were injected $(0.6 \mu \mathrm{L})$ by auto-sampler into a gas chromatograph equipped with a flame ionisation detector (Agilent Technologies 7890A, Wilmington, USA) and separated on a $100 \mathrm{~m} \times 0.25 \mathrm{~mm}$ i.d. fused-silica capillary column (CP-Sil 88, Chrompack, Middelburg, The Netherlands). A reference standard butter (CRM 164, Commission of the European Communities, Community Bureau of Reference, Brussels, Belgium) was used to estimate correction factors for short-chain FA (C4:0 to C10:0). Identification of FAME was accomplished by comparison to a standard mixture purchased from $\mathrm{Nu}$-Chek-Prep, Inc. (Elysian, MN 56028 USA). Mixtures of cis/trans (9-12) isomers of linoleic acid methyl ester and cis and trans (9-11) and (10-12) isomers of CLA methyl esters purchased from Sigma-Aldrich Corporation (38297 Saint Quentin Fallavier, France) were used for complete identification.

\section{Statistical analysis}

Data were averaged per period and per animal and analyzed using the Mixed procedure of SAS version 9.4 (SAS Institute, 2004). Data from HSD and HFD were analyzed separately as comparison between diets was not the objective of the study. The following model was used: $\mathrm{Y}_{i j k}=\mu+\mathrm{T}_{i}+\mathrm{P}_{j}+\mathrm{C}_{k}+\mathrm{e}_{i j k}$, where: $\mathrm{Y}_{i j k}$ are observations for dependent variables; $\mu$ is the overall mean; $T_{i}$ is the fixed effect of DFM (control, Propionibacterium, $L$. pentosus and $L$. bulgaricus); $\mathrm{P}_{j}$, is the fixed effect of period $(j=1-4) ; C_{k}$ is the random effect of cow; and $\mathrm{e}_{i j k}$ 
is the random residual error. The effect of individual DFM supplementation was tested using Dunnett's test, whereas orthogonal contrasts were performed to evaluate the effect of CTL versus all DFM treatments. Data were considered significant at $P<0.05$, and trends were discussed at $0.05<P \leq 0.10$.

\section{Results and discussion}

In this study, we tested the effects of bacterial DFM on enteric $\mathrm{CH}_{4}$, ruminal fermentation parameters, milk production and composition and the quantity of ruminal microbes in lactating primiparous dairy cows fed two contrasting diets differing in starch and fiber contents. Differences induced by diets (shown in Tables 2, 3 and supplementary Tables) were as expected for diets of similar composition [10] and are not further discussed as they were not the aim of the study. Additionally, the effects of these type of diets on ruminal fermentation and production are well documented [10].

\section{Enteric methane and ruminal fermentation}

Cows supplemented with Propionibacterium numerically emitted more $\mathrm{CH}_{4}$ than CTL particularly with HSD (Table 2). When calculated as $\mathrm{CH}_{4}$ intensity expressed in $\mathrm{g} / \mathrm{kg}$ milk, Propionibacterium increased emission by $27 \%$ $(P<0.05)$. Supplementation of L. bulgaricus or L. pentosus did not affect daily $\mathrm{CH}_{4}$ emission $(\mathrm{g} / \mathrm{d})$, yield or intensity $(P>0.05)$. Concentrations of total VFA and $\mathrm{NH}_{3}-\mathrm{N}$, and VFA profile were similar among DFM treatments for both diets (Additional file 2: Table S2).
Previous studies have shown that the effect of bacterial DFM in the rumen can vary depending on the type of DFM strain, physiological conditions of the animal [26], and composition of diet $[4,10,11]$. In studies using Propionibacterium acidipropionici strains P169 and P5 and Propionibacterium jensenii $\mathrm{P} 54$, reduced $\mathrm{CH}_{4}$ emissions (g $\mathrm{CH}_{4} / \mathrm{kg}$ DMI) were reported in beef steers fed a high-forage diet [4], whereas the same strains failed to show any effect on beef heifers fed a high-grain diet [11]. A similar observation was reported by Philippeau et al. [10] using a combination of P. jensenii and Lactobacillus plantarum. The combined DFM decreased $\mathrm{CH}_{4} / \mathrm{kg}$ DMI in lactating cows fed low starch diet but was ineffective with a high starch diet. It was suggested that the efficacy of Propionibacteria to increase propionate levels in the rumen and subsequently reduce $\mathrm{CH}_{4}$ emissions might not be observed with high-grain diets where propionate concentration is naturally high [11]. The increases in $\mathrm{CH}_{4}$ emissions observed with the supplementation of $P$. freudenreichii 53-W in our study cannot be explained by the above hypothesis as, as mentioned above, there were no changes in VFA profiles (Additional file 2: Table S2). However, in our previous study with wethers, this strain also increased $\mathrm{CH}_{4}$ emissions $\left(\mathrm{g} \mathrm{CH}_{4} / \mathrm{kg} \mathrm{DMI}\right)$ [5] and a similar observation (increased trend in $\mathrm{g} \mathrm{CH}_{4} / \mathrm{kg}$ DMI) was reported by Vyas et al. [27] in beef heifers fed a mixed diet (60:40 forage to concentrate ratio on DM basis) with Propionibacterium supplementation (P. freudenreichii T114, T54 and P. thoenii T159). In the present study, the starch level of HSD was similar to the study of Vyas et al. [27]. This

Table 2 Enteric methane $\left(\mathrm{CH}_{4}\right)$ emissions of lactating cows fed high-starch or high-fiber diets (CTL) supplemented with bacterial direct-fed microbials (DFM) Propionibacterium freudenreichii 53 W (PF), Lactobacillus pentosus D31 (LP), and Lactobacillus bulgaricus D1 (LB)

\begin{tabular}{|c|c|c|c|c|c|c|c|}
\hline \multirow[t]{2}{*}{$\mathrm{CH}_{4}$ emissions } & \multicolumn{4}{|c|}{ Treatment } & \multirow[t]{2}{*}{$\mathrm{SEM}^{\mathrm{a}}$} & \multicolumn{2}{|l|}{$P$-value } \\
\hline & $\overline{\mathrm{CTL}}$ & $\mathrm{PF}$ & LP & $L B$ & & Treatment & $\mathrm{CTL}$ vs DFM ${ }^{\mathrm{b}}$ \\
\hline \multicolumn{8}{|l|}{$\mathrm{CH}_{4}, \mathrm{~g} / \mathrm{d}$} \\
\hline High-starch diet & 286.4 & 327.8 & 303.9 & 271.4 & 21.12 & 0.33 & 0.56 \\
\hline High-fiber diet & 290.8 & 310.0 & 301.4 & 292.3 & 9.79 & 0.51 & 0.38 \\
\hline \multicolumn{8}{|l|}{$\mathrm{CH}_{4}, \mathrm{~g} / \mathrm{kg} \mathrm{DMl}$} \\
\hline High-starch diet & 20.0 & 22.8 & 21.3 & 18.7 & 2.19 & 0.62 & 0.72 \\
\hline High-fiber diet & 23.9 & 24.8 & 24.0 & 24.0 & 1.16 & 0.93 & 0.81 \\
\hline \multicolumn{8}{|l|}{$\mathrm{CH}_{4}, \mathrm{~g} / \mathrm{kg}$ milk } \\
\hline High-starch diet & 13.1 & $16.7^{*}$ & 14.6 & 12.6 & 0.78 & 0.02 & 0.12 \\
\hline High-fiber diet & 18.9 & 18.7 & 18.2 & 19.0 & 1.53 & 0.98 & 0.87 \\
\hline \multicolumn{8}{|l|}{$\mathrm{CH}_{4}, \mathrm{~g} / \mathrm{kg} \mathrm{ECM}$} \\
\hline High-starch diet & 12.6 & 15.6 & 14.4 & 12.5 & 1.02 & 0.15 & 0.22 \\
\hline High-fiber diet & 18.1 & 17.4 & 17.0 & 18.9 & 1.11 & 0.64 & 0.80 \\
\hline
\end{tabular}

${ }^{\mathrm{a}} \mathrm{SEM}$-standard error of the means

${ }^{\mathrm{b}} \mathrm{P}$-value for control vs all direct-fed microbials (DFM) within each diet

${ }^{C}$ ECM-energy corrected milk $[(0.327 \times \mathrm{kg}$ of milk $)+(12.95 \times \mathrm{kg}$ of fat $)+(7.65 \times \mathrm{kg}$ of protein $)]$

*Significantly $(P \leq 0.05)$ different from CTL group 
Table 3 Intake, milk production, milk composition and body weight (BW) gain of lactating cows fed high-starch or high-fiber diets (CTL) supplemented with bacterial direct-fed microbials (DFM) Propionibacterium freudenreichii 53 W (PF), Lactobacillus pentosus D31 $(\mathrm{LP})$, and Lactobacillus bulgaricus D1(LB)

\begin{tabular}{|c|c|c|c|c|c|c|c|}
\hline \multirow[t]{2}{*}{ Items } & \multicolumn{4}{|c|}{ Treatment } & \multirow[t]{2}{*}{$\mathrm{SEM}^{\mathrm{a}}$} & \multicolumn{2}{|l|}{$P$-value } \\
\hline & $\overline{\mathrm{CTL}}$ & PF & LP & $L B$ & & Treatment & CTL vs DFM \\
\hline \multicolumn{8}{|c|}{ Dry matter intake, $\mathrm{kg} / \mathrm{d}$} \\
\hline High-starch diet & 14.3 & 14.5 & 14.5 & 14.6 & 0.69 & 0.99 & 0.80 \\
\hline High-fiber diet & 12.2 & 12.5 & 12.6 & 12.3 & 0.72 & 0.97 & 0.74 \\
\hline \multicolumn{8}{|l|}{ Water intake, L/d } \\
\hline High-starch diet & 53.1 & 62.9 & 62.0 & 59.2 & 5.78 & 0.65 & 0.25 \\
\hline High-fiber diet & 56.5 & 50.7 & 47.5 & 51.6 & 3.25 & 0.33 & 0.11 \\
\hline \multicolumn{8}{|l|}{ Milk, kg/d } \\
\hline High-starch diet & 22.1 & 19.7 & 20.9 & 21.6 & 0.79 & 0.23 & 0.18 \\
\hline High-fiber diet & 16.3 & 16.9 & 17.0 & 15.6 & 1.40 & 0.89 & 0.90 \\
\hline \multicolumn{8}{|l|}{ Fat, $\mathrm{g} / \mathrm{kg}$ milk } \\
\hline High-starch diet & 37.0 & 40.1 & 36.1 & 36.1 & 2.57 & 0.66 & 0.88 \\
\hline High-fiber diet & 38.7 & 41.4 & 41.1 & 37.7 & 2.85 & 0.75 & 0.68 \\
\hline \multicolumn{8}{|l|}{ Protein, $\mathrm{g} / \mathrm{kg}$ milk } \\
\hline High-starch diet & 29.7 & 30.6 & 30.1 & 29.9 & 2.10 & 0.99 & 0.83 \\
\hline High-fiber diet & 27.1 & 27.8 & 27.9 & 26.3 & 1.38 & 0.82 & 0.91 \\
\hline \multicolumn{8}{|l|}{$\mathrm{ECM}^{\mathrm{c}}, \mathrm{kg} / \mathrm{d}$} \\
\hline High-starch diet & 22.7 & 21.2 & 21.3 & 22.1 & 0.70 & 0.41 & 0.17 \\
\hline High-fiber diet & 16.4 & 17.9 & 18.0 & 15.8 & 1.16 & 0.47 & 0.55 \\
\hline \multicolumn{8}{|l|}{ Efficiency ${ }^{\mathrm{d}}$, } \\
\hline High-starch diet & 1.60 & 1.46 & 1.48 & 1.52 & 0.08 & 0.65 & 0.27 \\
\hline High-fiber diet & 1.35 & 1.45 & 1.42 & 1.28 & 0.05 & 0.20 & 0.62 \\
\hline \multicolumn{8}{|l|}{ Body weight gain, kg } \\
\hline High-starch diet & -6.0 & $11.7^{\natural}$ & $13.0^{4}$ & 5.7 & 4.98 & 0.08 & 0.02 \\
\hline High-fiber diet & -3.0 & 4.2 & 0.5 & -3.2 & 7.85 & 0.89 & 0.71 \\
\hline
\end{tabular}

${ }^{\mathrm{a}} \mathrm{SEM}$-standard error of the means

${ }^{\mathrm{b}} P$-value for control vs all direct-fed microbials (DFM) within each diet

${ }^{c}$ ECM-energy corrected milk $[(0.327 \times \mathrm{kg}$ of milk $)+(12.95 \times \mathrm{kg}$ of fat $)+(7.65 \times \mathrm{kg}$ of protein $)]$

${ }^{\mathrm{d}}$ Efficiency $=\mathrm{ECM} /$ Dry matter intake

${ }^{\text {I }} 0.05<P \leq 0.10$ from $C T L$ group

can partly explain the similar results between these studies.

A possible reason of DFM failure is that added bacteria were not active or not present in sufficient numbers to have a detectable effect. The viability of the bacterial DFM inocula was tested before utilization and their presence was assessed in the rumen $3 \mathrm{~h}$ after administration. The abundance of all three DFM $3 \mathrm{~h}$ after administration was higher (tenfold or more) when compared to CTL cows $(P<0.05$; Fig. 1$)$. However, it can not be excluded that these concentrations were not high enough to modulate ruminal functions. The doses used for the three DFM was chosen based on our previous study in wethers [9] and also for practical considerations of industrial production. These doses are comparable and rather in the high end of the range found in the literature $[4,10,11,27,28]$. For the effect of DFM supplementation on the numbers of other ruminal microbial groups, there was no effect on $16 \mathrm{~S}$ rRNA copy numbers of total bacteria and mcrA copy numbers of total methanogens. Similarly, no treatment effect was observed in total protozoal counts or protozoal profile (Additional file 3: Table S3).

\section{Dry matter intake, milk production and composition}

DFM supplementation did not influence DMI, milk production or protein and fat yields (Table 3). Improvements in milk production (4.6\%) were reported in multiparous dairy cows (with 3 or more lactations) fed a high-grain diet supplemented with Propionibacterum strain P169 [28]. In the same study no difference in milk production was observed with Propionibacterium 


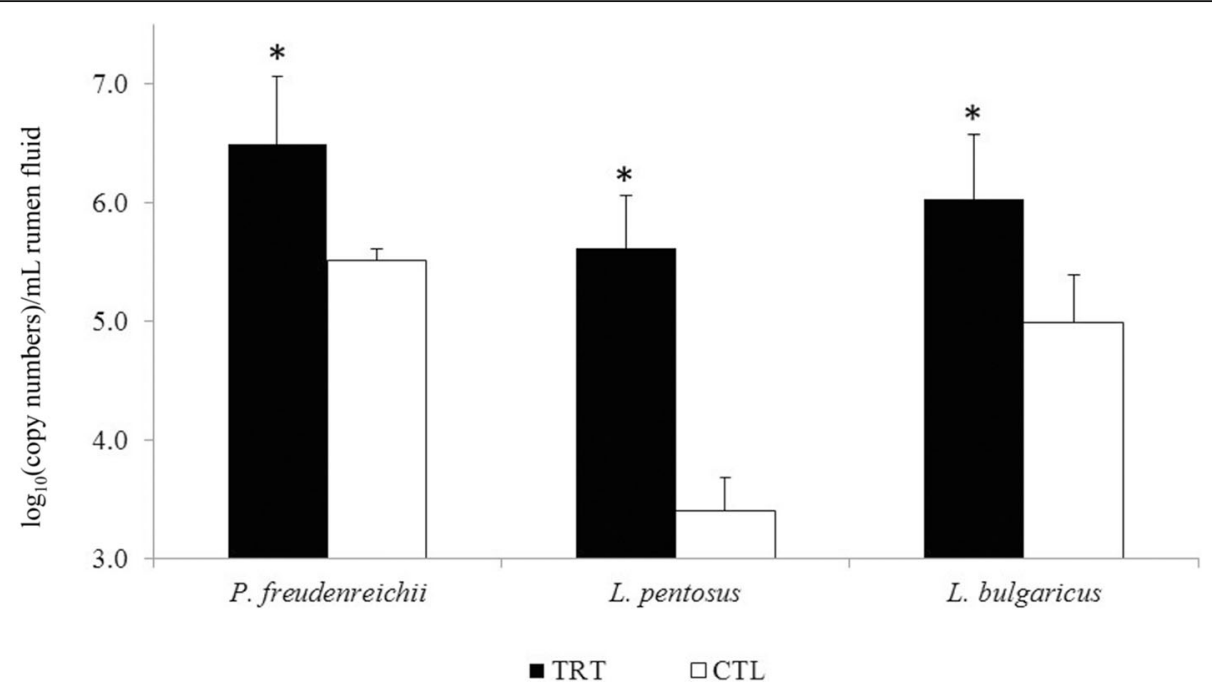

Fig. 1 Average abundance of 16S rRNA copies of Propionibacterium freudenreichii (PF) and Lactobacillus bulgaricus, and 16S-23S intergenic region copies of Lactobacillus pentosus in the rumen of dairy cows fed high-starch (HSD) and high-fiber diets (HFD), collected $3 \mathrm{~h}$ after administration of direct-fed microbials. CTL-Control cows (in white), TRT-DFM treated cows (in black). Please note that $Y$ axis starts at 3 and not $0 .{ }^{*}$ significantly $(P \leq 0.05)$ different from $C T L$ group

supplementation in younger dairy cows (up to 2 lactations). A similar finding on milk production was reported in dairy cows fed a total mixed ration supplemented with Propionibacterium strain P169 [26], in which the positive effect of the DFM was more marked in multiparous than in primiparous cows. The studies cited above suggest that parity may have an influence on the response to DFM, with primiparous cows, like the ones used in our study, being less reactive. More in vivo studies needed to confirm this suggestion. Notwithstanding, strain particularities and other factors might also be involved.

Although we did not find any effect of individual DFM on milk performance, BW increased when HSD was supplemented with DFM $(P<0.05$; Table 3$)$. These changes in BW were mainly driven by Propionibacterium and L. pentosus. Although not statistically significant, a similar numerical trend in BW was observed when HFD was supplemented with DFM. Improved energy balance and increased BW in Propionibacterium-treated cows were observed previously by Francisco et al. [29] in early lactation cows. In our study, the restriction of DMI to $90 \%$ of the ad libitum intake may have exacerbated a potential influence of Propionibacterium and L. pentosus on the energy balance and partitioning in cows fed HSD. Numerically lower milk production in cows fed HSD with Propionibacterium supplementation resulted in increased $\mathrm{CH}_{4}$ intensity expressed in $\mathrm{g} / \mathrm{kg}$ milk $(P<0.05)$. The metabolic shift that may have been induced by these bacterial DFM could be due to the physiological status of primiparous dairy cows that mobilize significantly less body reserves than second- and third-parity cows [30]. This mode of action beyond the gastrointestinal tract should be further explored using a larger number of both primiparous and multiparous lactating cows.

\section{Milk fatty acid composition}

Milk fatty acids were determined because they can be used as proxies to estimate $\mathrm{CH}_{4}$ emissions [31]. Also, several strains of Propionibacterium and Lactobacillus species have been identified as potential producers of conjugated linoleic acids (CLA) [32]. In this study, the milk FA composition was affected by diet as expected (statistics not presented) but DFM induced almost no effect (Additional file 4: Table S4).Additional file 4: Table S4 shows also some other minor changes that were particularly detected using orthogonal contrasts.

Apas et al. [33] showed that supplementation of a mixture of Enterococcus, Lactobacillus and Bifidobacterium strains modified milk FA composition of goats with increases in cis-9, trans-11 CLA content. In contrast, we did not see any changes in milk cis-9, trans-11 CLA concentration due to DFM supplementation. The absence of clear changes in the FA profile of milk is in line with other observations.

\section{Conclusions}

The bacterial DFM P. freudenreichii 53-W increased $\mathrm{CH}_{4}$ emissions intensity $\left(\mathrm{g} \mathrm{CH}_{4} / \mathrm{kg}\right.$ milk) when cows were fed a high starch diet, whereas, none of the DFM used (P. freudenreichii 53-W, L. pentosus D31 or L. bulgaricus D1) affected ruminal fermentation and production parameters in lactating primiparous dairy cows irrespective of diet. 
Most information on the effect of DFM on ruminal fermentation and $\mathrm{CH}_{4}$ reduction has been obtained in vitro. The results of this work should be taken as a cautionary note as bacteria selected for their modulating activities in vitro were not able to induce similar effects in vivo and for one DFM the opposite effect was observed for $\mathrm{CH}_{4}$ emission. Although discrepancy between in vitro and in vivo studies is generally known, published studies on this aspect are scarce. Reporting these kinds of studies, where the original hypothesis was not supported by the results, is necessary for an unbiased body of information. To explain this discrepancy, it is important that in future work, strains should be clearly identified, and doses and mode of administration stated.

\section{Additional files}

Additional file 1: Table S1. Primers used in this study. (DOCX $33 \mathrm{~kb}$ )

Additional file 2: Table S2. Ruminal fermentation parameters of lactating cows fed high-starch (HSD) or high-fiber diets (HFD) supplemented with bacterial direct-fed microbials (DFM) Propionibacterium freudenreichii 53 W (PF), Lactobacillus pentosus D31 (LP), and Lactobacillus bulgaricus D1 (LB). (DOCX $33 \mathrm{~kb}$ )

Additional file 3: Table S3. Ruminal concentration of bacteria, archaea, and protozoa (per $\mathrm{mL}$ rumen fluid) of lactating cows fed high-starch (HSD) or high-fiber diets (HFD) supplemented with bacterial direct-fed microbials (DFM) Propionibacterium freudenreichii 53 W (PF), Lactobacillus pentosus D31 (LP), and Lactobacillus bulgaricus D1 (LB). (DOCX $31 \mathrm{~kb}$ )

Additional file 4: Table S4. Major milk fatty acid (FA) composition of cows fed high-starch (HSD) or high-fiber diets (HFD) supplemented with bacterial direct-fed microbials (DFM) Propionibacterium freudenreichii $53 \mathrm{~W}$ (PF), Lactobacillus pentosus D31 (LP), and Lactobacillus bulgaricus D1 (LB). (DOCX $69 \mathrm{~kb}$ )

\section{Abbreviations}

ADF: Acid detergent fibre; CFU: Colony forming units; CP: Crude protein; CTL: Control without DFM; DFM: Direct-fed microbials; DMI: Dry matter intake; FA: Fatty acid; FAME: Fatty acid methyl esters; GE: Gross energy; h: Hour; HFD: High-fibre diet; HSD: High-starch diet; NDF: Neutral detergent fibre

\section{Acknowledgements}

We thank D. Roux, J. Bourdassol, F. Rosa and S. Rudel (UE1414 Herbipôle) and P. G. Toral (UMR Herbivores) for animal care and assistance in sample collection; and Y. Rochette, D. Graviou and C. Delavaud (UMR Herbivores) for their help in laboratory analysis.

\section{Funding}

Funding for the study was from Danone Research, Palaiseau, France. MP and DM acknowledge support from METHLAB a FACCE ERA-GAS project in collaboration with the French National Research Agency (ANR).

\section{Availability of data and materials}

All data analysed during this study are included in this article and its supplementary files.

\section{Authors' contributions}

DM, CM and JJ conceived and designed the experiments. JJ, CM and ME carried out the experiments. JJ, ME, AF and MP analysed the samples. DM and JJ wrote the manuscript. CM, ME, AF and MP provided critical discussions during revision. All authors read and approved the final manuscript.

\section{Ethics approval}

The study was approved by the Auvergne regional ethic committee for animal experimentation, approval number CE05-12.

\section{Consent for publication}

Not applicable.

\section{Competing interests}

The authors declare that they have no competing interests.

\section{Author details}

${ }^{1}$ Université Clermont Auvergne, INRA, VetAgro Sup, UMR 1213 Herbivores, F-63122 Saint-Genès-Champanelle, France. ${ }^{2}$ Present address: Laboratory for Animal Nutrition and Animal Product Quality, Faculty of Bioscience Engineering, Ghent University, Coupure Links 653, 9000 Ghent, Belgium.

Received: 30 November 2018 Accepted: 11 March 2019

Published online: 02 May 2019

\section{References}

1. Gerber PJ, Steinfeld H, Henderson B, Mottet A, Opio C, Dijkman J, et al. Tackling climate change through livestock - A global assessment of emissions and mitigation opportunities. Rome: Food and Agriculture Organization of the United Nations (FAO); 2013.

2. Johnson KA, Johnson DE. Methane emissions from cattle. J Anim Sci. 1995; 73:2483-92.

3. Hristov AN, Oh J, Giallongo F, Frederick TW, Harper MT, Weeks HL, et al. An inhibitor persistently decreased enteric methane emission from dairy cows with no negative effect on milk production. Proc Natl Acad Sci USA. 2015.

4. Vyas D, McGeough EJ, McGinn SM, McAllister TA, Beauchemin KA. Effect of Propionibacterium spp. on ruminal fermentation, nutrient digestibility, and methane emissions in beef heifers fed a high-forage diet. J Anim Sci. 2014; 92:2192-201.

5. Jeyanathan J, Martin C, Morgavi DP. The use of direct-fed microbials for mitigation of ruminant methane emissions: a review. Animal. 2014;8:250-61.

6. Adams MC, Luo J, Rayward D, King S, Gibson R, Moghaddam GH. Selection of a novel direct-fed microbial to enhance weight gain in intensively reared calves. Anim Feed Sci Tech. 2008;145:41-52.

7. McAllister TA, Beauchemin KA, Alazzeh AY, Baah J, Teather RM, Stanford K. Review: the use of direct fed microbials to mitigate pathogens and enhance production in cattle. Can J Anim Sci. 2011;91:193-211.

8. Marvin-Sikkema FD, Richardson AJ, Stewart CS, Gottschal JC, Prins RA. Influence of hydrogen-consuming bacteria on cellulose degradation by anaerobic fungi. Appl Environ Microbiol. 1990;56:3793-7.

9. Jeyanathan J, Martin C, Morgavi DP. Screening of bacterial direct-fed microbials for their antimethanogenic potential in vitro and assessment of their effect on ruminal fermentation and microbial profiles in sheep. J Anim Sci. 2016;94:739-50

10. Philippeau C, Lettat A, Martin C, Silberberg M, Morgavi DP, Ferlay A, et al. Effects of bacterial direct-fed microbials on ruminal characteristics, methane emission, and milk fatty acid composition in cows fed high- or low-starch diets. J Dairy Sci. 2017;100:2637-50.

11. Vyas D, McGeough EJ, Mohammed R, McGinn SM, McAllister TA, Beauchemin KA. Effects of Propionibacterium strains on ruminal fermentation, nutrient digestibility and methane emissions in beef cattle fed a corn grain finishing diet. Animal. 2014;8:1807-15.

12. Lettat A, Noziere P, Silberberg M, Morgavi D, Berger C, Martin C. Rumen microbial and fermentation characteristics are affected differently by bacterial probiotic supplementation during induced lactic and subacute acidosis in sheep. BMC Microbiol. 2012;12:142.

13. INRA. Nutrition of cattle, sheep and goats: animal needs - feed values. Quae Editions: Paris; 2007

14. International_Standarization_Organization. Animal feeding stuffs Determination of moisture and other volatile matter content. ISO 6496 AFNOR V18A 1999

15. AOAC. Official methods of analysis of AOAC international. 16th ed. Washington: AOAC International; 2005.

16. van Soest PJ, Robertson JB, Lewis BA. Methods for dietary fiber, neutral detergent fiber, and nonstarch polysaccharides in relation to animal production. J Dairy Sci. 1991;74:3583-97. 
17. Faisant N, Planchot V, Kozlowski F, Pacouret MP, Colonna P, Champ M. Resistant starch determination adapted to products containing high levels of resistant starch. Sci Aliments. 1995;15:83-9.

18. Guyader J, Eugène $M$, Meunier $B$, Doreau $M$, Morgavi DP, Silberberg $M$, et al. Additive methane-mitigating effect between linseed oil and nitrate fed to cattle. J Anim Sci. 2015;93:3564-77.

19. Pinares-Patino CS, Hunt C, Martin R, West J, Lovejoy P, Waghorn G. Chapter 1: New Zealand ruminant methane measurement Centre, AgResearch, Palmerston North. In: Pinares-Patino CS, Waghorn G, editors. Technical manual on respiration chamber designs. Wellington; 2012. p. 9-28.

20. Morgavi DP, Boudra H, Jouany JP, Graviou D. Prevention of patulin toxicity on rumen microbial fermentation by SH-containing reducing agents. J Agric Food Chem. 2003:51:6906-10.

21. Park GE, Oh HN, Ahn S. Improvement of the ammonia analysis by the phenate method in water and wastewater. B Korean Chem Soc. 2009;30: 2032-8.

22. Ranilla MJ, Jouany JP, Morgavi DP. Methane production and substrate degradation by rumen microbial communities containing single protozoal species in vitro. Lett Appl Microbiol. 2007:45:675-80.

23. Yu Z, Morrison M. Improved extraction of PCR-quality community DNA from digesta and fecal samples. Biotechniques. 2004;36:808-12.

24. Popova $M$, Martin $C$, Eugène $M$, Mialon MM, Doreau M, Morgavi DP. Effect of fibre- and starch-rich finishing diets on methanogenic Archaea diversity and activity in the rumen of feedlot bulls. Anim Feed Sci Tech. 2011;166167:113-21.

25. Ferlay A, Doreau M, Martin C, Chilliard Y. Effects of incremental amounts of extruded linseed on the milk fatty acid composition of dairy cows receiving hay or corn silage. J Dairy Sci. 2013;96:6577-95.

26. Stein DR, Allen DT, Perry EB, Bruner JC, Gates KW, Rehberger TG, et al. Effects of feeding propionibacteria to dairy cows on milk yield, milk components, and reproduction. J Dairy Sci. 2006;89:111-25.

27. Vyas D, Alazzeh A, McGinn SM, McAllister TA, Harstad OM, Holo H, et al. Enteric methane emissions in response to ruminal inoculation of Propionibacterium strains in beef cattle fed a mixed diet. Anim Prod Sci. 2016:56:1035-40

28. de Ondarza MB, Seymour WM. Effect of propionibacteria supplementation on yield of milk and milk components of dairy cows. Prof Anim Sci. 2008;24: 254-9.

29. Francisco CC, Chamberlain CS, Waldner DN, Wettemann RP, Spicer LJ. Propionibacteria fed to dairy cows: effects on energy balance, plasma metabolites and hormones, and reproduction. J Dairy Sci. 2002;85:1738-51.

30. Friggens NC, Berg P, Theilgaard P, Korsgaard IR, Ingvartsen KL, Lovendahl P, et al. Breed and parity effects on energy balance profiles through lactation: evidence of genetically driven body energy change. J Dairy Sci. 2007;90: 5291-305.

31. Negussie E, de Haas Y, Dehareng F, Dewhurst RJ, Dijkstra J, Gengler N, et al. Invited review: large-scale indirect measurements for enteric methane emissions in dairy cattle: a review of proxies and their potential for use in management and breeding decisions. J Dairy Sci. 2017;100:2433-53.

32. Yang B, Gao H, Stanton C, Ross RP, Zhang H, Chen YQ, et al. Bacterial conjugated linoleic acid production and their applications. Prog Lipid Res. 2017:68:26-36.

33. Apas AL, Arena ME, Colombo S, Gonzalez SN. Probiotic administration modifies the milk fatty acid profile, intestinal morphology, and intestinal fatty acid profile of goats. J Dairy Sci. 2015;98:47-54.

Ready to submit your research? Choose BMC and benefit from:

- fast, convenient online submission

- thorough peer review by experienced researchers in your field

- rapid publication on acceptance

- support for research data, including large and complex data types

- gold Open Access which fosters wider collaboration and increased citations

- maximum visibility for your research: over $100 \mathrm{M}$ website views per year

At BMC, research is always in progress.

Learn more biomedcentral.com/submissions 